\title{
The Crystal Structure of DL-Pentane-2,4-diol as a Model Compound for Poly(vinyl alcohol)
}

\author{
Shunsuke KURIBAYASHI \\ Government Industrial Research Institute, \\ Osaka, Midorigaoka, Ikeda 563, Japan
}

(Received July 25, 1983)

\begin{abstract}
The crystal structure of DL-pentane-2,4-diol as a model compound of syndiotactic poly(vinyl alcohol) was determined. This crystal belongs to a monoclinic system with the dimensions of $a=12.266(2), b=8.886(1), c=11.693(3) \AA$, and $\beta=92.94(4)^{\circ}$. The space group was $\mathrm{P} 2_{1} / n$ and $\mathrm{D}_{m}=1.08, \mathrm{D}_{c}=1.086$ and $Z=8$. The final $R$ factor was 0.083 for 1891 observed reflections. There are two crystallographically independent molecules in the unit cell. The five carbon atoms of these molecules have TT sequences and the $\mathrm{OH}$ groups form intermolecular hydrogen bonds. A structure analysis suggests that the conformation of syndiotactic poly(vinyl alcohol) may take TT sequences, the carbon chain has a planar zigzag form and the hydroxyl groups form intermolecular hydrogen bonds.

KEY WORDS Crystal Structure / DL-Pentane-2,4-diol / Syndiotactic Poly(vinyl alcohol) / TT Sequence /
\end{abstract}

The structure of stereoregular vinyl polymers is of great interest. Generally speaking, stereoregular polymers are more crystallizable than atactic polymers. In the case of poly(vinyl alcohol), however, even atactic polymers are highly crystallizable. The structure of PVA of various tacticities were investigated by NMR, ${ }^{9-14}$ IR, and X-ray diffraction. ${ }^{1-8}$ To elucidate the conformation, configuration, and crystal structure of PVA, many investigations of model compounds such as 2,4-pentanediol, 2,4,6-heptanetriol, and their derivatives were carried out by NMR, ${ }^{15-21} \mathrm{IR},{ }^{22,32}$ and $\mathrm{X}$ ray $^{23-25}$ methods. The present paper reports the crystal structure of DL-pentane-2,4-diolthe dimer for syndiotactic poly(vinyl alcohol).

\section{EXPERIMENTAL}

The crystal used was prepared from an ethanol solution and its crystal data appear in Table I. The cell dimensions were determined by the least squares method, using 20 reflections.

The size of the crystal was about $0.1 \times$ $0.2 \times 0.4 \mathrm{~mm}^{3}$. Measurement was made by a Rigaku four-circle diffractometer. The $\omega-2 \theta$ scan mode was applied, using graphite monochromatized Mo- $K \alpha$ radiation with a scan range of $\Delta \omega=1.2+0.5 \tan \theta$. Lorentz and polarization corrections were made, but none for absorption and secondary extinction effects.

Table I. Crystal data

\begin{tabular}{|c|c|}
\hline Chemical formula & $\mathrm{C}_{5} \mathrm{H}_{12} \mathrm{O}_{2}$ \\
\hline Molecular weight & 104.15 \\
\hline Space group & $\mathrm{P} 2_{1} / n$ \\
\hline Cell constants & $\begin{array}{l}a=12.266(2) \AA \\
b=8.886(1) \AA \\
c=11.698(3) \AA \\
\beta=92.94(4)^{\circ}\end{array}$ \\
\hline Volume of unit cell & $V=1273.4(4)$ \\
\hline Density & \\
\hline Obsd & 1.08 \\
\hline Calcd & 1.086 \\
\hline $\begin{array}{l}\text { Number of molecules } \\
\text { in the unit cell }\end{array}$ & $Z=8$ \\
\hline
\end{tabular}




\section{STRUCTURE DETERMINATION}

The structure was analyzed by the Nordman-Nakatsu method, using a Pauling type sharpened Patterson function under the assumption that the five carbon atoms take TT sequences. The Eulerian angles of the molecules and their origins were determined. The structure was refined by the block-diagonalleast-squares method, excluding unobserved reflections. The function $\sum w(\Delta F)^{2}$ with $w=$ $\left(1+0.1 F_{0}+0.001 F_{0}{ }^{2}\right)^{-1}$ was minimized. The final $R$ factor was 0.083 for 1891 observed reflections. The atomic scattering factors were taken from the International Tables for X-ray Crystallography. ${ }^{26}$ The positional parameters of the hydrogen atoms bonded to carbon atoms were calculated geometrically, assuming that $\mathrm{CH}$ bond lengths are $1.09 \AA$ and the bond angles of the carbon atoms remain tetrahedral and fixed during the least sequence refinement. But those bonded to oxygen atoms were determined by difference Fourier synthesis. The isotropic thermal factors of hydrogen atoms were assumed to be the same as those of nonhydrogen atoms to which they are bonded.

Table II. Atomic positional parameters and their ESD'S in parentheses

\begin{tabular}{ccccc}
\hline Atom & $x$ & $y$ & $z$ & $B \mathrm{eq} / \AA^{2}$ \\
\hline $\mathrm{C}(1,1)$ & $0.3340(5)$ & $0.4230(6)$ & $0.4559(5)$ & 5.87 \\
$\mathrm{C}(1,2)$ & $0.3218(3)$ & $0.3951(4)$ & $0.3283(4)$ & 4.26 \\
$\mathrm{C}(1,3)$ & $0.2036(3)$ & $0.3813(4)$ & $0.2845(3)$ & 3.99 \\
$\mathrm{C}(1,4)$ & $0.1874(3)$ & $0.3728(4)$ & $0.1556(4)$ & 4.31 \\
$\mathrm{C}(1,5)$ & $0.0696(4)$ & $0.3396(6)$ & $0.1171(5)$ & 5.89 \\
$\mathrm{O}(1,1)$ & $0.3803(2)$ & $0.2613(3)$ & $0.2987(3)$ & 4.92 \\
$\mathrm{O}(1,2)$ & $0.2205(3)$ & $0.5147(3)$ & $0.1098(3)$ & 4.77 \\
$\mathrm{C}(2,1)$ & $0.6239(4)$ & $0.6872(4)$ & $0.1291(5)$ & 4.98 \\
$\mathrm{C}(2,2)$ & $0.6669(3)$ & $0.5332(4)$ & $0.1670(3)$ & 3.26 \\
$\mathrm{C}(2,3)$ & $0.5927(3)$ & $0.4062(4)$ & $0.1197(3)$ & 3.50 \\
$\mathrm{C}(2,4)$ & $0.6235(3)$ & $0.2520(4)$ & $0.1673(3)$ & 3.44 \\
$\mathrm{C}(2,5)$ & $0.5619(4)$ & $0.1278(5)$ & $0.1049(4)$ & 4.57 \\
$\mathrm{O}(2,1)$ & $0.7726(2)$ & $0.5084(3)$ & $0.1260(2)$ & 3.94 \\
$\mathrm{O}(2,2)$ & $0.6043(2)$ & $0.2477(3)$ & $0.2881(2)$ & 3.91 \\
\hline
\end{tabular}

The coordinates and isotropic thermal factors for the nonhydrogen atoms are listed in Table II, and those of hydrogen atoms in Table III.*

\section{RESULTS AND DISCUSSION}

The ORTEP ${ }^{27}$ drawings of the molecules are shown in Figure 1. The numbering of all atoms is shown in Figure 2. The crystal structures viewed along the $b$ and $c$ axes are shown in Figures 3 and 4, respectively. It is evident that the five carbon atoms are nearly on the same plane for each of the two independent molecules, and take TT conformations, and two pairs of intermolecular hydrogen bonds are formed between the two molecules related by the two-fold screw axes. The two crystallographically independent molecules are also linked

Table III. Atomic positional parameters and isotropic temperature factors of $\mathbf{H}$ atoms

\begin{tabular}{cccccc}
\hline Atom & $x$ & $y$ & $z$ & $B$ & Bonded to \\
\hline $\mathrm{H}(1)$ & 0.418 & 0.433 & 0.483 & 6.13 & $\mathrm{C}(1,1)$ \\
$\mathrm{H}(2)$ & 0.797 & 0.169 & 0.002 & 6.13 & $\mathrm{C}(1,1)$ \\
$\mathrm{H}(3)$ & 0.208 & 0.027 & 0.023 & 6.13 & $\mathrm{C}(1,1)$ \\
$\mathrm{H}(4)$ & 0.357 & 0.496 & 0.293 & 4.55 & $\mathrm{C}(1,2)$ \\
$\mathrm{H}(5)$ & 0.157 & 0.478 & 0.310 & 4.27 & $\mathrm{C}(1,3)$ \\
$\mathrm{H}(6)$ & 0.172 & 0.282 & 0.326 & 4.27 & $\mathrm{C}(1,3)$ \\
$\mathrm{H}(7)$ & 0.229 & 0.273 & 0.126 & 4.46 & $\mathrm{C}(1,4)$ \\
$\mathrm{H}(8)$ & 0.061 & 0.333 & 0.024 & 6.19 & $\mathrm{C}(1,5)$ \\
$\mathrm{H}(9)$ & 0.017 & 0.429 & 0.145 & 6.19 & $\mathrm{C}(1,5)$ \\
$\mathrm{H}(10)$ & 0.042 & 0.234 & 0.153 & 6.19 & $\mathrm{C}(1,5)$ \\
$\mathrm{H}(11)$ & 0.344 & 0.205 & 0.329 & 5.62 & $\mathrm{O}(1,1)$ \\
$\mathrm{H}(12)$ & 0.278 & 0.005 & 0.461 & 6.82 & $\mathrm{O}(1,2)$ \\
$\mathrm{H}(13)$ & 0.823 & 0.275 & 0.337 & 5.34 & $\mathrm{C}(2,1)$ \\
$\mathrm{H}(14)$ & 0.881 & 0.194 & 0.464 & 5.34 & $\mathrm{C}(2,1)$ \\
$\mathrm{H}(15)$ & 0.958 & 0.204 & 0.341 & 5.34 & $\mathrm{C}(2,1)$ \\
$\mathrm{H}(16)$ & 0.838 & 0.039 & 0.242 & 3.82 & $\mathrm{C}(2,2)$ \\
$\mathrm{H}(17)$ & 0.506 & 0.423 & 0.139 & 3.86 & $\mathrm{C}(2,3)$ \\
$\mathrm{H}(18)$ & 0.600 & 0.411 & 0.029 & 3.86 & $\mathrm{C}(2,3)$ \\
$\mathrm{H}(19)$ & 0.706 & 0.225 & 0.147 & 3.64 & $\mathrm{C}(2,4)$ \\
$\mathrm{H}(20)$ & 0.586 & 0.020 & 0.141 & 5.07 & $\mathrm{C}(2,5)$ \\
$\mathrm{H}(21)$ & 0.475 & 0.142 & 0.112 & 5.07 & $\mathrm{C}(2,5)$ \\
$\mathrm{H}(22)$ & 0.580 & 0.128 & 0.015 & 5.07 & $\mathrm{C}(2,5)$ \\
$\mathrm{H}(23)$ & 0.680 & 0.091 & 0.351 & 3.58 & $\mathrm{O}(2,1)$ \\
$\mathrm{H}(24)$ & 0.542 & 0.222 & 0.304 & 7.72 & $\mathrm{O}(2,2)$ \\
\hline & & & & &
\end{tabular}

* The anisotropic thermal factors of the nonhydrogen atoms and the list of the observed and calculated structure factors will be provided by the author on request. 

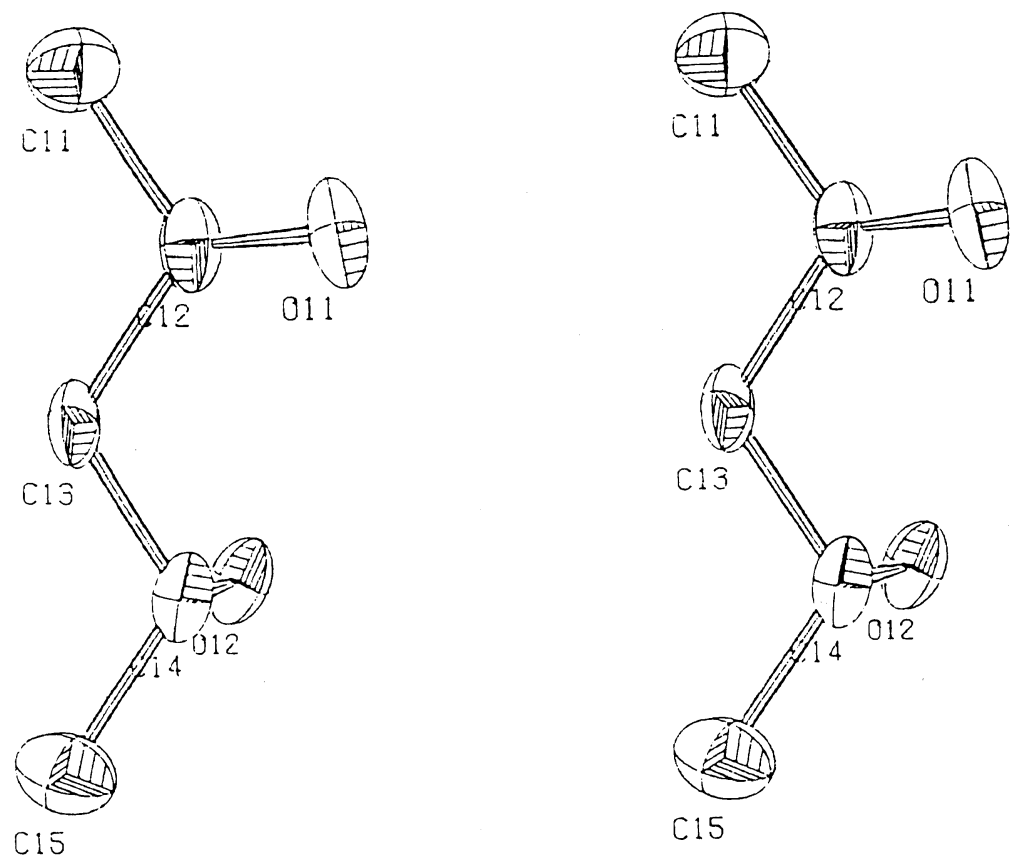

(a)

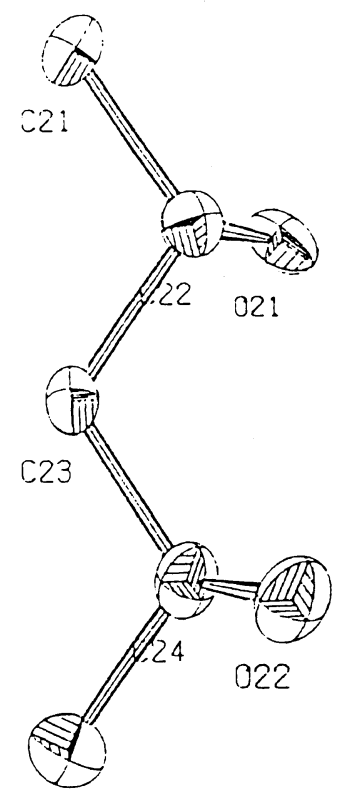

C25

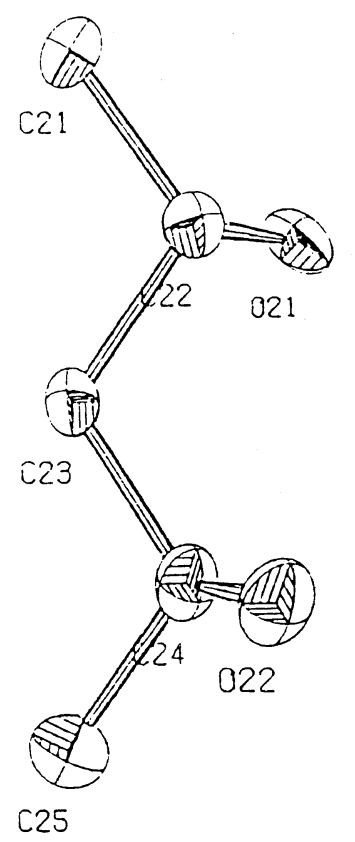

(b)

Figure 1. Stereodrawings of DL-pentane-2,4-diol. First molecule (a), and second molecule (b). The thermal ellipsoids are drawn at $30 \%$ probability level. 


\section{S. KURIBAYASHI}
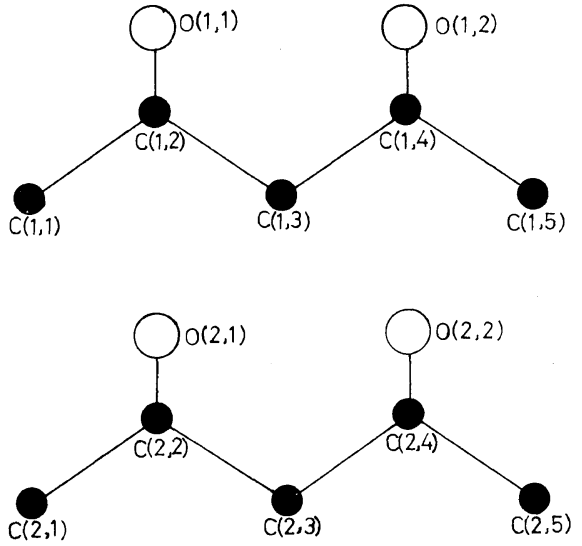

together by intermolecular hydrogen bonds, one being nearly parallel to the $a$-axis and the other to the $c$-axis. Around the center of symmetry, eight $\mathrm{OH}$ groups are linked together by hydrogen bonds, forming octagons, four sides of which are parallel to the opposite sides. One pair of these sides point in the direction of the $a$-axis and are nearly in (040) and $(0 \overline{4} 0)$. Another pair is in the direction of

Figure 2. Numbering of the atoms. The first numbers in parentheses indicate the numbering of molecules and the second numbers, that of atoms in one molecule.

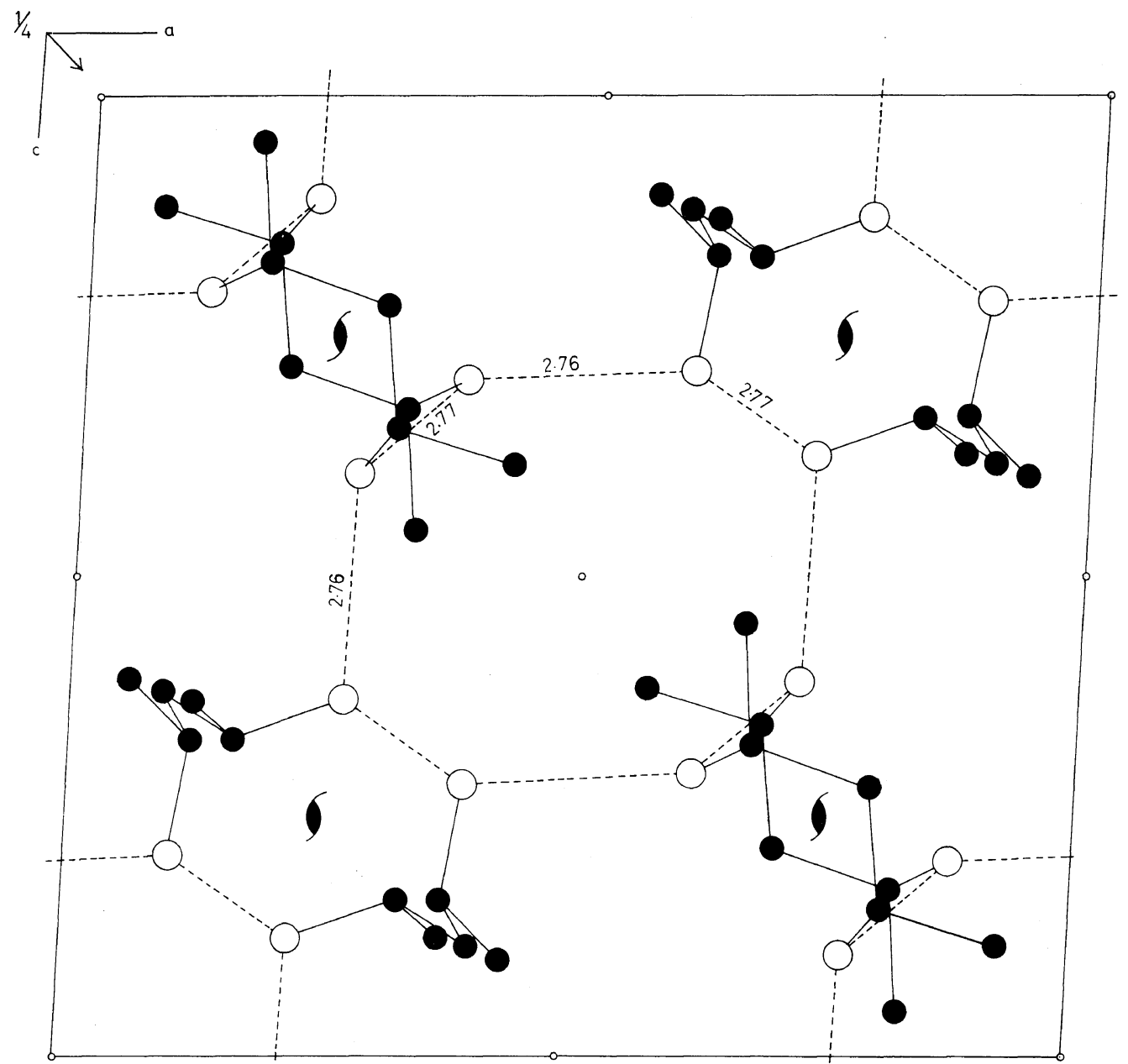

Figure 3. The crystal structure viewed along the $b$-axis. Broken lines indicate hydrogen-bonds. Filled circles indicate carbon atoms and unfilled circles, oxygen atoms. 


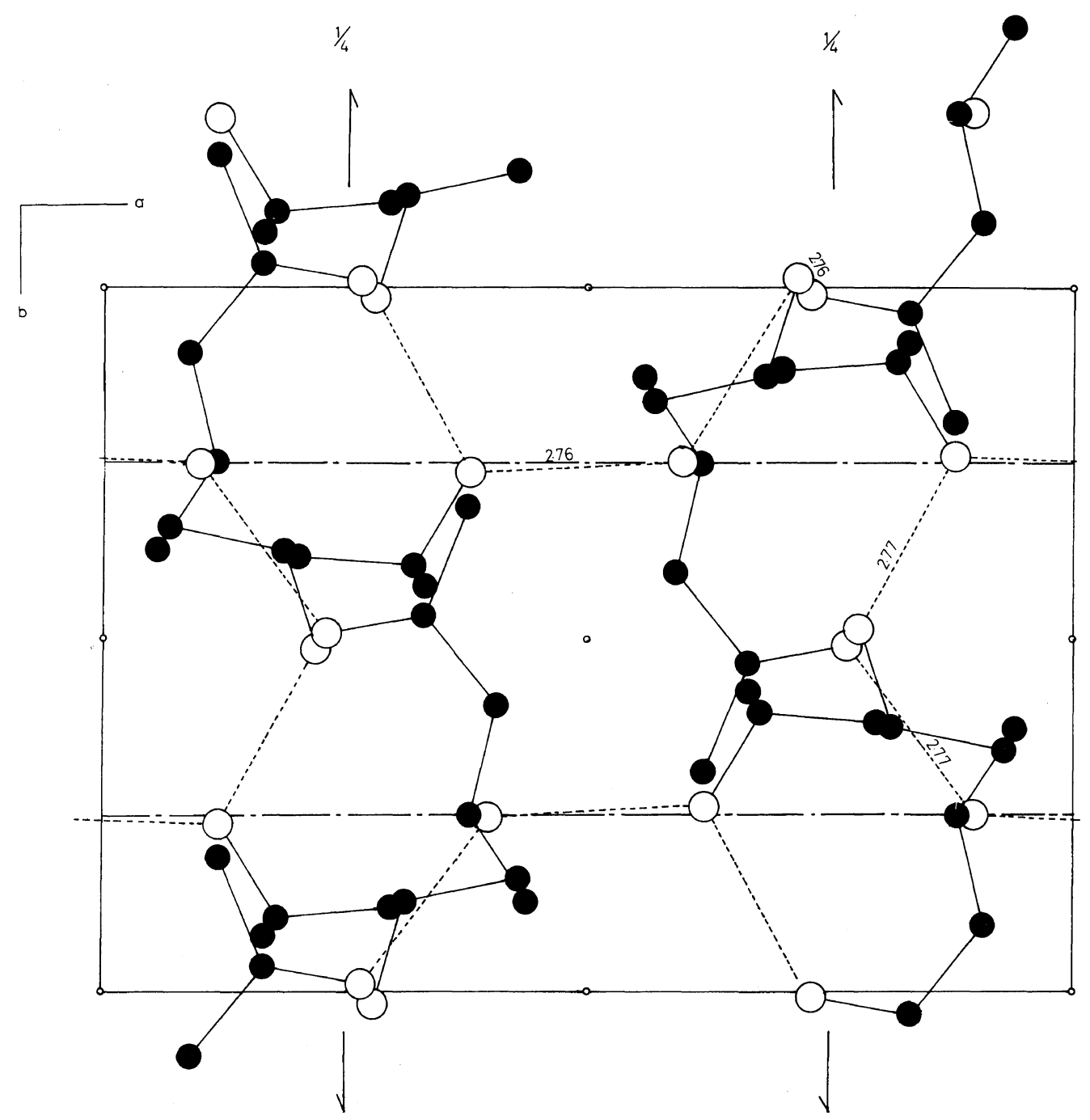

Figure 4. The crystal structure viewed along the $c$-axis. Other symbols are the same as in Figure 3.

the $c$-axis and situated nearly in the $(010)$ plane. As shown in Figure 3, the hydrogen bond lengths are 2.76 and $2.77 \AA$. The shortest van der Waals distances are 3.69 and $3.41 \AA$ for $\mathrm{C}-\mathrm{C}$ and $\mathrm{C}-\mathrm{O}$, respectively. These values are not significantly different from those obtained for ordinary organic compounds. The bond lengths and angles are shown in Table IV. The carbon to carbon bond lengths are 1.505 to $1.534 \AA$, and the carbon to oxygen bond lengths 1.423 to
$1.445 \AA$. These values are not particularly different from the mean values of 1.518 and $1.437 \AA$, respectively. The bond angles of $\mathrm{C}$ $\mathrm{C}-\mathrm{C}$ ranging from 111.4 to $114.5^{\circ}$ with the mean value of $112.8^{\circ}$ are somewhat larger than the $\mathrm{C}-\mathrm{C}-\mathrm{O}$ bond angles, ranging from 107.3 to $110.6^{\circ}$ with a mean value of $109.4^{\circ}$. These results agree with those obtained for various saccharides and polyols. ${ }^{24,25,28-30}$ The bond angles of the central carbon atoms for the two independent molecules 
Table IV. Bond lengths $(\AA)$ and angles of the two molecules

\begin{tabular}{lcc}
\hline & Molecule 1 & Molecule 2 \\
\hline $\mathrm{C}(1)-\mathrm{C}(2)$ & $1.513(7)$ & $1.524(5)$ \\
$\mathrm{C}(2)-\mathrm{C}(3)$ & $1.519(5)$ & $1.534(5)$ \\
$\mathrm{C}(3)-\mathrm{C}(4)$ & $1.512(5)$ & $1.519(5)$ \\
$\mathrm{C}(4)-\mathrm{C}(5)$ & $1.520(6)$ & $1.505(5)$ \\
$\mathrm{C}(2)-\mathrm{O}(1)$ & $1.441(5)$ & $1.423(4)$ \\
$\mathrm{C}(4)-\mathrm{O}(2)$ & $1.437(5)$ & $1.445(4)$ \\
$\mathrm{C}(1)-\mathrm{C}(2)-\mathrm{C}(3)$ & $113.0^{\circ}(4)$ & $111.4^{\circ}(3)$ \\
$\mathrm{C}(2)-\mathrm{C}(3)-\mathrm{C}(4)$ & $114.5^{\circ}(3)$ & $113.6^{\circ}(3)$ \\
$\mathrm{C}(3)-\mathrm{C}(4)-\mathrm{C}(5)$ & $112.3^{\circ}(4)$ & $112.0^{\circ}(3)$ \\
$\mathrm{C}(1)-\mathrm{C}(2)-\mathrm{O}(1)$ & $110.3^{\circ}(4)$ & $110.4^{\circ}(3)$ \\
$\mathrm{C}(3)-\mathrm{C}(2)-\mathrm{O}(1)$ & $109.3^{\circ}(3)$ & $107.3^{\circ}(3)$ \\
$\mathrm{C}(3)-\mathrm{C}(4)-\mathrm{O}(2)$ & $107.7^{\circ}(3)$ & $109.4^{\circ}(3)$ \\
$\mathrm{C}(5)-\mathrm{C}(4)-\mathrm{O}(2)$ & $110.0^{\circ}(4)$ & $110.6^{\circ}(3)$ \\
\hline
\end{tabular}

Table V. The plane constants of the two molecular planes containing five carbon atoms with respect to crystallographic axes represented by $a x+b y+c z=d$

\begin{tabular}{rrrrr}
\hline & \multicolumn{1}{c}{$b$} & \multicolumn{1}{c}{$c$} & \multicolumn{1}{c}{$d$} \\
\hline Molecule 1 & -0.1037 & 0.9907 & -0.0825 & 2.823 \\
Molecule 2 & -0.6732 & -0.0765 & 0.7690 & 4.390 \\
\hline
\end{tabular}

are somewhat larger than the other $\mathrm{C}-\mathrm{C}$ $\mathrm{C}$ bond angles. The five carbon atoms are nearly on a plane for both molecules. These results are also in agreement with the data on DL-3-chloro-2,4-pentane-diol. ${ }^{24}$ The equations of the two molecular planes and distances of each atom to the planes are listed in Tables V and VI respectively. As can be understood from these equations, one molecular plane is nearly in (080) and the other, in (202). One molecular axis is nearly parallel to [101] and perpendicular to the $b$-axis and the other parallel to the $b$-axis. The torsional angles for $\mathrm{C}-\mathrm{C}-\mathrm{C}-\mathrm{C}$ and $\mathrm{C}-\mathrm{C}-\mathrm{C}-\mathrm{O}$ are listed in Table VII. These values indicate that the five carbon atoms take TT conformations. The angle between the two molecular planes is $94.05^{\circ}$; that is, the two planes intersect nearly perpendicularly. In the case of PVA polymers, the directions of the molecular chains in the unit cell were all in the $b$-axis, and the mo-
Table VI. Distances from each atom to the least square planes in $\AA$

\begin{tabular}{lrr}
\hline & Molecule 1 & Molecule 2 \\
\hline $\mathrm{C}(1)$ & 0.036 & 0.034 \\
$\mathrm{C}(2)$ & -0.071 & -0.084 \\
$\mathrm{C}(3)$ & -0.000 & 0.016 \\
$\mathrm{C}(4)$ & 0.070 & 0.085 \\
$\mathrm{C}(5)$ & -0.035 & -0.052 \\
$\mathrm{O}(1)$ & -1.295 & -1.343 \\
$\mathrm{O}(2)$ & 1.322 & 1.327 \\
\hline
\end{tabular}

Table VII. Torsion angles of the two molecules $\theta^{\circ}$

\begin{tabular}{ccc}
\hline & Molecule 1 & Molecule 2 \\
\hline $\mathrm{C}(1)-\mathrm{C}(2)-\mathrm{C}(3)-\mathrm{C}(4)$ & 172.7 & 172.5 \\
$\mathrm{C}(2)-\mathrm{C}(3)-\mathrm{C}(4)-\mathrm{C}(5)$ & 172.9 & 170.3 \\
$\mathrm{C}(4)-\mathrm{C}(3)-\mathrm{C}(2)-\mathrm{C}(1)$ & 172.7 & 172.5 \\
$\mathrm{C}(5)-\mathrm{C}(4)-\mathrm{C}(3)-\mathrm{C}(2)$ & 172.9 & 170.3 \\
$\mathrm{C}(2)-\mathrm{C}(3)-\mathrm{C}(4)-\mathrm{O}(2)$ & -65.9 & -66.7 \\
$\mathrm{C}(4)-\mathrm{C}(3)-\mathrm{C}(2)-\mathrm{O}(1)$ & -63.95 & -66.5 \\
\hline
\end{tabular}

lecular plane parallel with each other. ${ }^{6}$ In the case of low molecular weight compounds, however, this is not necessarily the case. The packing of the molecules is such that all the $\mathrm{OH}$ groups form intermolecular hydrogen bondings with two independent molecules in TT conformations.

The results obtained by the structure analysis of DL-pentane-2,4-diol crystals suggest that syndiotactic PVA molecules take a TT planar zigzag conformation and that the $\mathrm{OH}$ groups tend to be linked together by intermolecular hydrogen bonds.

However, if the above principle is justifiable, the $5.0 \AA$ fiber period with two monomeric unit should be observed, but it was not for syndiotactic-rich PVA. Only a $2.5 \AA$ fiber period with one monomeric unit was observed in syndiotactic-rich polymers. This was also the case for isotactic-rich and atactic PVA. Halle, Hoffman, ${ }^{34}$ and Mooney ${ }^{35}$ suggested that the crystalline parts of conventional PVA consist of isotactic parts. However, Bunn ${ }^{6}$ reported later that the fiber period of $2.5 \AA$ may also be explained by considering that the crystalline regions contain atactic comformation. 
Kakinoki $^{36}$ and Sakurada ${ }^{37}$ later proposed a model in which the syndiotactic zigzag chains are displaced randomly by $2.5 \AA$ upwards and downward in the direction of the fiber axis. On the basis of very accurate X-ray diffraction data on conventional PVA samples, Taguchi $^{33}$ concluded that the alternative appearance of $\mathrm{OH}$ groups on both sides of the carbon backbone chains is more probable than the $\mathrm{OH}$ groups appearing on the same sides of the carbon backbone chain. The $2.5 \AA$ fiber period is interpretable by this model. However, the fact that single crystals could be obtained from conventional atactic PVA led, Fujii ${ }^{31}$ to the conclusion that the stereostructure of conventional PVA is the same as the model proposed by Bunn. In the case of isotactic type heptane-triol crystals, the seven carbon atoms take GTTG sequences and all the $\mathrm{OH}$ groups are linked together by intermolecular hydrogen bonds; i.e., the carbon chain is crooked at both ends of the molecule. If the isotactic poly(vinyl alcohol) molecules tend to take conformations preventing the intramolecular hydrogen bonding with the adjacent $\mathrm{OH}$ group, entanglement may occur even in relatively short chains. Isotactic PVA is rather poor in crystallinity. Murahashi et $a{ }^{7}$ concluded that the low crystallizability of isotactic PVA may be ascribed to smaller intermolecular interactions which owe to the absence of intermolecular hydrogen bonds. In contrast, we suspect that the low crystallizability of isotactic PVA is due to the repulsive force acting between adjacent $\mathrm{OH}$ groups in one molecule; thus the carbon chains are unable to take regular planar zigzag forms.

Kenney and Willkockson ${ }^{5}$ reported that the order of crystallizability of PVA was atactic $\geqq$ syndiotactic $\gg$ isotactic-rich, within the range of tacticity studied. Nagano, Fujita, and Nakatsuka $^{8}$ reported that, in the temperature range from 100 to $180^{\circ} \mathrm{C}$, crystallization proceeded in the order, syndiotactic-rich $>$ atactic $>$ isotactic-rich. However, the crystal struc- ture of isotactic, syndiotactic, and atactic PVA are essentially the same. ${ }^{31}$ Mechanical treatment, such as stretching and spinning, may affect the conformation and hydrogen bonding of the molecules. From the results obtained for the DL-pentane-2,4-diol and the isotactic type heptane triol, however, we suspect that syndiotactic PVA is more crystallizable than isotactic or atactic PVA. When completely syndiotactic PVA, with a sufficiently high degree of polymerization can be synthesized, it should be worthwhile to examined whether the fiber period of $5.0 \AA$ or diffuse scattering of this period can be observed or not.

\section{REFERENCES}

1. K. Fujii, T. Mochizuki, S. Imoto, J. Ukida, and M. Matsumoto, J. Polym. Sci., A, 2, 2327 (1964).

2. T. Shimanouchi, J. Polym. Sci., C, 7, 85 (1963).

3. S. Murahashi, S. Nozakura, M. Sumi, and K. Matsumura, J. Polym. Sci., Polym. Lett. Ed., 4, 59 (1966).

4. S. Murahashi, S. Nozakura, and M. Sumi, J. Polym. Sci., Polym. Lett. Ed., 3, 245 (1965).

5. J. F. Kenney and G. W. Willcockson, J. Polym. Sci., A-1, 4, 679 (1966).

6. C. W. Bunn, Nature, 161, 929 (1948).

7. S. Murahashi, H. Yuki, T. Sano, U. Yonemura, H. Tadokoro, and Y. Chatani, J. Polym. Sci., 62, S77 (1962).

8. M. Nagano, M. Fujita, and H. Nakatsuka, Kobunshi Kagaku, 24, 746 (1967).

9. Von J. Bargon, K. H. Hellwege, and U. Johnsen, Makromol. Chem., 85, 291 (1965).

10. W. C. Tincher, Makromol. Chem., 85, 46 (1965).

11. R. P. Gupta and R. C. Laible, J. Polym. Sci., A, 3, 3951 (1965).

12. T. Moritani, I. Kuruma, K. Shibatani, and Y. Fujiwara, Macromolecules, 5, 577 (1972).

13. K. C. Ramey and D. C. Lini, J. Polym. Sci., Polym. Lett. Ed., 5, 39 (1967).

14. K. C. Ramey and N. D. Field, J. Polym. Sci., Polym. Lett. Ed., 3, 63 (1965).

15. S. Satoh, R. Chujo, and E. Nagai, Rep. Prog. Polym. Phys. Jpn., 5, 251 (1962).

16. D. Doskočilová, J. Stokr, E. Votanová, B. Schneider, and D. Lim, J. Polym. Sci., C, 16, 2225 (1967).

17. D. Lim, E. Votanová, J. Stokr, and J. Petranek, J. Polym. Sci., Polym. Lett. Ed., 4, 581 (1966).

18. K. Shibatani, Y. Fujiwara, and K. Fujii, J. Polym. Sci., A-1, 8, 1693 (1973).

19. Kalenipihlaja, T. Launosalo, and P. Äyräs, Acta 


\section{S. KURIBAyASHI}

Chem. Scand., 23, 2299 (1969)

20. T. Fukuroi, Y. Fujiwara, and S. Fujiwara, Anal. Chem., 40, 879 (1968).

21. Y. Fujiwara and S. Fujiwara, J. Polym. Sci., A-1, 4, 257 (1966)

22. K. Fujii, J. Polym. Sci., Polym. Lett. Ed., 3, 375 (1965).

23. S. Kuribayashi, Bull. Chem. Soc. Jpn., 39, 2784 (1966), ibid., 46, 1045 (1973).

24. S. Kuribayashi, Bull. Chem. Soc. Jpn., 48, 2336 (1975).

25. S. Kuribayashi, Bull. Chem. Soc. Jpn., 47, 545 (1974).

26. "International Tables for X-Ray Crystallography," Vol. IV, Kynoch Press, Birmingham, England, 1974.

27. C. K. Johnson, "ORTEP," Report ORNL-3794, Oak Ridge National Laboratory, Oak Ridge, Tenn., 1976.
28. H. S. Kim, G. A. Jeffrey, and R. D. Rosenstein, Acta Crystallogr., Sect. B, 25, 2223 (1969).

29. N. Azarnia, G. A. Jeffrey, and M. S. Shen, Acta Crystallogr., Sect. B, 28, 1007 (1972).

30. H. M. Berman, G. A. Jeffrey, and R. D. Rosenstein, Acta Crystallogr., Sect. B, 24, 442 (1968).

31. K. Fujii, J. Polym. Sci., Macromol. Rev., D, 5, 431 (1971).

32. E. Nagai, S. Kuribayashi, M. Shiraki, and M. Ukita, J. Polym. Sci., 35, 295 (1959).

33. "X-Ray Crystallography," Vol. I, I. Nitta Ed., Maruzen, Tokyo, Japan, 1959, p 564.

34. F. Halle and W. Hoffman, Naturwiss., 45, 770 (1935).

35. R. Mooney, J. Amer. Chem. Soc., 63, 2828 (1941).

36. J. Kakinoki, Ann. Rept. Inst. Fiber Res., 5, 19 (1950).

37. I. Sakurada, K. Fuchino, and N. Okada, Bull. Inst. Chem. Res. Kyoto Univ., 23, 78 (1950). 